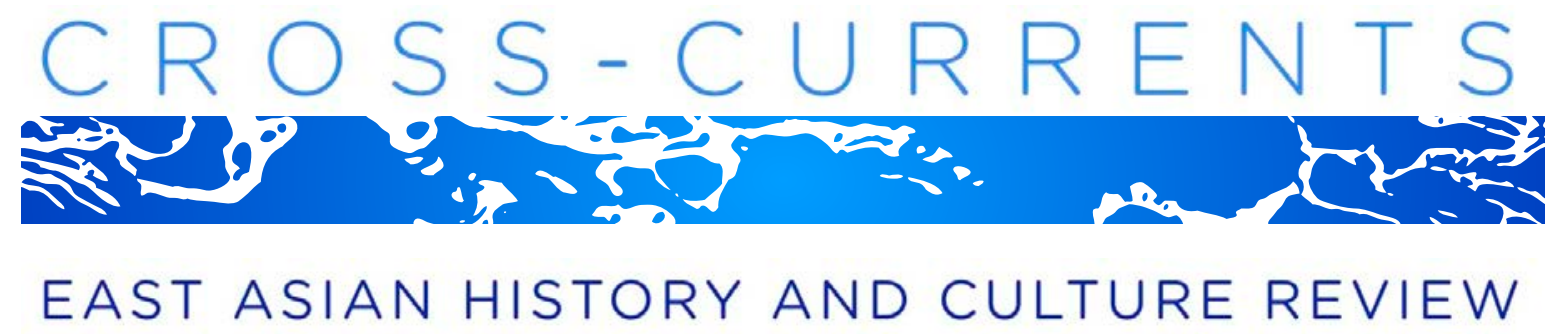

\title{
China in Islam: Turki Views from the Nineteenth and Twentieth Centuries
}

Rian Thum, Loyola University New Orleans

\begin{abstract}
This article questions dominant understandings of "China," "Islam," and the relationship between the two. It does so by uncovering an alternative understanding of China, one held by a group of people living within the Qing Empire and, later, the Republic of China: the Turkispeaking Muslims of Altishahr, known today as Uyghurs. Turki manuscript sources depict China as a distant and distasteful power, as a khanate in the Inner Asian tradition, and as a city synonymous with its ruler, characterized above all else by its rejection of Islam, yet vulnerable to conversion by charismatic Sufis. This notion of China, it is argued, is no more culturally determined than the predominant understanding of China that undergirds most scholarly studies of China, and no less enlightening. And yet Altishahri and other Islamic perspectives have been excluded from our notion of China, largely through a dependence on the concept of "syncretism." As an alternative to the syncretism approach to cultural interchange, the article advocates for a greater focus on overlapping networks of shared meaning. Applied to the Altishahri case, this approach gives a sense of what is lost in the privileging of Islam and China as dominant categories, and shows the distortions involved in bounding these categories.
\end{abstract}

Keywords: Islam, China, syncretism, Uyghur

Scholars have long recognized that the notion of "China" is a culturally specific construction, and yet it seems impossible to escape the Chinese construction of China. The problems with the predominant construction of "China" are exacerbated by the fact that it reflects the ideology of a conquering state at the expense of dominated groups like the Tibetans and Altishahris. This article questions the dominant essentialization of China by examining China from the perspective of one of its conquered populations: the people of Altishahr. Chronologically, it focuses on the nineteenth century and the first three decades of the twentieth century, an era when manuscripts were produced and used in large numbers. 
The Altishahris discussed here were Turki-speaking, sedentary Muslim inhabitants of the region they knew as Altishahr (also known as Eastern Turkestan, Chinese Turkestan, Kashgaria, or Xinjiang Nanlu), which came under China-based control in 1759. Since the 1930s, the Altishahri identity has been transformed into a "Uyghur" ethnonational identity roughly contiguous with its Altishahri predecessor, and it is under the Uyghur name that the Altishahris' descendants are known today.

The Altishahri/Uyghur cultural complex has never been granted the status of civilizational center by outsiders. Among non-Uyghur scholars today, it tends to be defined as marginal from two perspectives. For Sinologists the Altishahri story fits into "frontier studies," and for Islamicists it falls into the category of "Islam at the margins." Of course, like most communities, the Uyghurs and their ancestors did not consider themselves to be marginal in the least, and this self-understanding led them to develop constructions of China that relegated it to the status of a powerful but ultimately distasteful other. I argue below that the distinctive characteristics of this understanding reflect both particularly Altishahri cultural traits and Altishahr's participation in wider networks of cultural significance, including the larger Islamic world, Central Asian Sufi networks, the sphere of Inner Asian political legitimacy, and IndoPersian narrative traditions.

This view of overlapping networks of meaning challenges some of the conceptual underpinnings of the field of "Islam in China," in particular the clean compartmentalization of Islam and China, along with models of "syncretism" predicated on such compartmentalization. Compartmentalization is foundational to syncretism models, because the idea of mixing religions postulates ideal unmixed forms, deceptively clean units like true (nonsyncretic) Islam or true Daoism. Syncretism has, of course, been criticized on these grounds before, in relation to other traditions (e.g., Martin 1996), and its usefulness has even been challenged from within the field of Islam in China (Gladney 1987, 501). However, this brand of essentializing syncretism has survived as a foundational concept in both Chinese- and English-language scholarship (e.g., Lipman 1998; Israeli 2002; Frankel 2011; Hai 2013). The example of Altishahri notions of China points up some of the particular distortions this has created for our understandings of China and Islam.

I have attempted to make sense of the idiosyncrasies of Altishahri views of China not by imagining "influences," or unidirectional, one-time transfers of meaning between stable cultural 
units or identity groups, but instead by tracing the many overlapping regional and global communities of shared cultural meanings ("networks of significance," "networks of meaning") of which most Altishahris were members. As the nuances of Altishahr's China are unraveled, it becomes clear that Altishahris have tapped a wide variety of networks of significance and exchange to understand their strange neighbor, not limiting themselves to the networks we are most comfortable with (religion: Islam, state: Qing/China, ethnic group: Altishahri). In addition to these obvious networks, Inner Asian networks of political legitimacy, Indo-Persian literary culture, transregional Sufi preaching networks, and local networks of pilgrimage and historical practice have shaped Altishahri visions of China, and through these visions, the interactions between the Chinese state and Central Asian Muslims. These conclusions give a sense of what is lost in the privileging of Islam and China as dominant categories, and show the distortions involved in bounding these categories.

\section{Two Chinas}

There is a terminological divide in the manuscripts of nineteenth- and early twentiethcentury Altishahr. On one hand, those that are derived from earlier sources speak frequently of "Chīn and Māchīn" (hereafter, Chin and Machin), employing medieval Perso-Arabic terminology for the eastern half of Altishahr, in particular the region of Khotan, or for China proper. On the other hand, among the texts composed under Qing rule, the few that refer to the Qing Empire or the Republic of China do so by the terms "Khițāy," "Chīn," "Chīn city," "Bijīn," or "people of Bijīn" (hereafter, Khitay, Chin, and Bijin). This latter group of terms, by virtue of its continued use throughout the first half of the twentieth century, portrays the Qing Empire and the Republic of China as essentially the same entity. ${ }^{1}$ The present essay will introduce the older "Chin and Machin" concept briefly, before undertaking a more thorough analysis of the later Khitay/Chin/Bijin cluster of terms.

"Chin and Machin" appears frequently in the most popular of Altishahr's historical genres, the tazkirah, or local hagiography. In particular, it is a staple concept in a group of tazkirahs that describe the spread of Islam into Altishahr through holy wars. Internal evidence suggests that these texts are descended from oral epics, many narrating the Qarakhanid conquests of Altishahr in the tenth and eleventh centuries C.E. The identification of Chin and Machin (usually, but not always, used together) with the Altishahri oasis of Khotan is clear in most cases 
from context, and in at least one case from an explanatory statement in the text; a manuscript of the Tazkirah-i Imām Ja far Tayarān reads, "When the four sacrificed imams came to Imam Țayarān's resting place from Mavarannahr, making the various cities of Kashgar, Yarkand, and Chin and Machin — that is to say [ya'ni] Khotan-Islamic..." (BaJT, f. 32a). Occasionally, Machin is used individually to denote Khotan, as in one manuscript of the Tazkirah-i Türt Imām Zabihlar, which uses "Machin city" (LuT2, f. 173a) where another recension of the same text has "Khotan city." (LuTI, f. 58a). The Altishahri understanding of Chin and Machin is roughly in line with the use of these names in earlier Persian texts, except that the Persian texts are more likely to distinguish between the two, associating Machin with the area around Khotan (as in LuT2) and Chin with a larger kingdom to the east (e.g., Firdawsī 1906, 256, 370).

A representative passage from The Tazkìrah of Imam Mūsá Käzìm [sic] demonstrates the role of Chin and Machin in the holy war narratives:

His grandfather said, "Oh Imam, Chin and Machin is without religion of any kind. They will oppress you. Do not go now." The imam did not agree and... he arrived at the region of Chin and Machin. His companions said, "Oh Imam, the ruler of this region is Malik Muzaffar, son of Toqqūz Khaqan. He is a faithless käfir. Your noble father and Imam Ja'far Șādiq found martyrdom at his hands." (SpMK, ff. $51 b-52 a)$

As in all of the holy war tazkirahs, Chin and Machin is significant as a land of unbelief, whose inhabitants are known only as käfirs (infidels), and as the site of martyrdom for the saints who lent their names to the various tazkirahs. Like other tazkirahs, these holy war tales were read aloud to pilgrims at the tombs of the saints described within them (Thum 2012). That is to say, the tales were performed in the very places described as Chin and Machin, teaching listeners that they were the new inhabitants of the land once known as Chin and Machin, a land that by their own time had been renamed as Khotan and converted to Islam. This understanding remains common in Khotan today, especially among people who frequent the local shrines, and I have often been told that the remains of ancient Chin and Machin can be found in the nearby desert.

For the most part, the distinction between the earlier "Chin and Machin" usage and the later "Khitay/Chin/Bijin" cluster of terms was clear in the texts that deployed them. The content and context of Altishahri texts left no doubt as to whether they were discussing pre-Islamic Khotan or contemporary Qing/Republican China. In most cases the terminology aligned neatly 
with this conceptual divide. However, this was not always the case; the word "Chin" was sometimes used alone to refer to Khotan. ${ }^{2}$ This created semantic overlap of the terminology for Qing/Republican China with the terminology for the Buddhist kingdom of Khotan that predated the Qarakhanid conquest. This overlap will be treated again below, following an analysis of Altishahri concepts of the Qing Empire and Republican China.

\section{Hidden China}

The most remarkable aspect of Altishahri depictions of Qing and Republican China is their rarity. For the century following the Qing conquest (1759), the China-based domination of Altishahr was elided in the vast majority of manuscript texts. This omission was temporarily addressed in the wake of the Muslim rebellions of 1864-1877, which led to the establishment of the Emirate of Kashgar and inspired a flood of new writing on local history. These new historical works were concerned primarily with the events of the rebellion itself, and therefore, by necessity, dealt with China in an explicit way. Yet the new histories received little attention from ordinary readers, and they were never copied in great numbers. Thus, for most readers the textual silence regarding China persisted until the next revolution, when, in 1933, the newspaper of the independent Republic of East Turkestan began to treat the relationship between Altishahr and China again.

The general silence on China in the Altishahri literary tradition was encouraged by the Qing strategy of indirect rule and Qing disinterest in integrating Xinjiang, the "new dominion," with interior China. A large force of primarily Manchu soldiers was split between Ili and Kashgar, but the day-to-day governing was carried out by Altishahri officials, who staffed a structure very similar to that which had preceded Qing rule. The highest level of Altishahri officials, and the only ones who had to deal directly with Manchu or Chinese superiors, were the begs, elites from families that had cooperated with the Qing during the conquest. These individuals were entrusted with the governing of entire oases. Because the Altishahri political tradition regarded non-Muslim rule as illegitimate, begs often presented themselves to their subjects as supreme rulers, making no mention of their Manchu overlords. Thus, for example, a Persian inscription commissioned by the beg of Yarkand, commemorating his renovation of an important shrine, called him 
the sultan who traverses the clime of integrity, chief among the rulers of the citadel of majesty, friend of the 'ulama and the pious, patron of the poor and the indigent, glory of the world and the religion, defender of Islam and the Muslims, promoter of the shari'at and devotee of justice, the plenipotentiary amir, hākim of Yarkand Yūnus Hāāim Beglik, son of Iskandar Wang Beglik, son of Emin Khwāja Wang Beglik. May God make his life and kingdom everlasting and increase his sultanate and his glory! ${ }^{3}$

Meanwhile, Yūnus's overlord, the non-Muslim Qing emperor, went unmentioned entirely.

Chinese immigration to Altishahr also had a limited impact. For the first half of Qing domination, immigration from the interior of China was discouraged, although criminals were often exiled to the Ili valley. In the ensuing century and a half, a growing number of Chinesespeaking immigrants engaged in inter-oasis trade, but their numbers remained small. Immigrants lived in special segregated quarters in major towns. Visitors' descriptions and photos show that apart from the immigrants' quarters in major cities, the population was strikingly homogeneous, consisting almost entirely of Altishahri people. For all these reasons, most Altishahri people, especially those in rural areas, had very limited contact with representatives of the government or culture of "China." There was rarely occasion in everyday life to imagine China.

\section{Mentions of Qing and Republican China}

Rare though it was, mention of Qing and Republican China did appear in the works of a few Altishahri authors. There is not space here for a transcript of all textual Altishahri references to China, though such an anthology would probably occupy no more than several dozen pages. Instead, I present the first appearance of China in each of those texts I have accessed that treat the subject. ${ }^{4}$ The picture that emerges is representative of both the variety of terminology and the consistency of certain features throughout and across the texts. These selections use the most common terms for the emperor of China (khaqan, khan, great khan) and the most common terms for China (Khitay, Chin, Bijin).

Of the texts presented here, only the first seems to have achieved any popularity. It is a hagiography of three Naqshbandi saints: Āfāq Khvāja (hereafter, Afaq Khoja), his son, and his father, Muḥammad Yūsuf (also known as Mazār Pādishāhim), whose proselytizing missions supposedly took him to China. The popularity of the text is due in part to its association with the tomb of Afaq Khoja, a major pilgrimage site in Kashgar. The remaining texts did not circulate 
widely, but they are important for their documentation of the authors' views on China. Text 2 is a rare verse account of the 1864 uprising against Qing rule in Ili, which was printed in Kazan. Selections 3 and 4 are from short manuscript texts commissioned by a Swedish missionary, Gustav Raquette, probably to provide material for his dictionary of the Turki language. Text 5 is a history of Altishahr with a focus on the uprisings of 1864 and the period of independence that followed. The final text is a unique, untitled continuation of text 5 by another author.

1) Then, being finished, [Muhammad Yūsuf] wished to go to [the?] khaqan of Chin. Then he went to Sukhur [Tibet, treated here as a part of the khaqan's territories]. And then in the end the people [who followed him] were numerous. At this time Khitay received an attack from the Qalmaqs.

-Anonymous, Tazkirah-i of Āfāq Khvājah [Biography of Afaq Khoja], middle of the nineteenth century (LuAK f. 11r)

2) When the time of the khan called Chen Long was reached, Uprooted people came to the city of Ili

From Kuchar and Aqsu, Shayar, and Bay,

And Yarkand, Kashgar, and Khotan,

All kinds of people moved to Ili,

And set up villages and tilled the earth.

From that moment to this moment a hundred-something years,

In service of the khaqan so many years.

The infidel oppressed and tyrannized the believers,

Taking barley, wheat, corn, and money.

The infidels' tyranny exceeded the limit, enough!

From Khitay the people saw hardships, enough!

—Mullā Bilāl, Ghazāt dar mulk-i Chīn [Holy war in China], (1880-1881, 9)

3) That which is called changchile [theatrical performance] has been a custom among the idolaters of the region of the khaqan, and it is similar to the custom of the Muslims' "book reciters" and the mullas who go around the bazaars preaching.

-Abdu Vali Akhon, Changchile Bayani [Description of theatrical performances] (c. 1905-1910, 1)

4) The seeds for vegetables are taken from the region of the khaqan.

—Abdu Vali Akhon, Otyash Bayani [Description of vegetables], (c. 1905-1910, 1)

5) ....and becoming victorious, Qublay Khan turned his inquiries to the country of Chin. The khaqan of Chin had a history book called Kangjang. It told the history of the khans. According to it, in the history of the Khitay people there appeared a descendent of Fung named Tay Khufus, and his rule was from Adam, peace be upon him.

—Mullā Mūsá Sayrāmī, Tārikh-i Hamīdī [The Hamidi history], (1911, 10r) 
6) In the year 1329 [1911 C.E.], Shentung Khan of Bijin had no children. He consulted with his mother, saying, "If I don't have a son, the business of the khanship will not go well. I must adopt a child and educate and teach and make known [to him] the business of the khan." So saying, he finished his advice. In the khan's yamun [yamen] there was a great official who was an intimate. The khan was inclined toward [this official's] son.

-Hājjī Ghulām Muḥammad Khān Khwājam, Kāshghar Mā Tìtaynīng Vāqi 'asi

[The events of Kashgar's Ma Titai] (a continuation of the Tārīkh-i Hamīdì), (1927, f. $124 \mathrm{v})$.

\section{Altishahri Impulses: China as Emperor, China as City}

In these texts, China is defined, above all else, by the emperor, called khan or khaqan. ${ }^{5}$ In his shadow, ethnic and linguistic distinctions, such as Chinese versus Manchu, are invisible. ${ }^{6} \mathrm{He}$ is not just the representative of China in all political affairs, but a synecdoche for China as a political entity and even as a geographic location. Thus, for Abdu Vali Akhon, China is "the region of the khaqan" (khāqān iqlīmi), and in the Tazkirah of Afaq Khoja, the khaqan of Chin is treated like a place, one of several destinations on the saint's globe-trotting itinerary: Mecca, Ferangi (Europe), khaqan of Chin, Sukhur, Sala, Kashgar, Qumul.

Such interchangeability of person and place is characteristic of Altishahr's popular historical tradition. As I have argued elsewhere (Thum 2014), in the late eighteenth and early nineteenth centuries, history was organized in Altishahr by personages and their associated places, rather than, say, chronologically. Local history was a patchwork of hagiographies, connected through geographic networks of pilgrimage. Ordinary people learned the histories of local saints through travel to shrines, at which the stories of the saints were recited. These stories were collected in anthologies that were geographically organized by the locations of the saints' graves. Towns were known by their entombed saints, and saints were known by the towns in which they were buried. The identification of China with a single powerful individual, typically represented in a caricatured form, fit accounts of China neatly into the Altishahri scheme of history.

This treatment extended to certain other external societies as well. In another section of the Tazkirah of Áfāq Khvāja, the word "Ferangi" is used both to denote a place (presumably somewhere in Europe) and the ruler of the place, who is sometimes called "the padishah of Ferangi" and sometimes simply "the Ferangi." The Qalmaqs (i.e., the Dzungar Mongols), who appeared in several of the works above, were more often described as a group of people than the 
Chinese or Europeans were, but they, too, were frequently represented by their "khan." Thus, the synecdoche of the khaqan for China seems to be an instance of a more general mode of imagining foreign powers.

Altishahri descriptions of China also reflect local understandings of geography, through the conflation of city and region. Hājjī Ghulām describes the emperor as the khan of Bijin (Beijing), and later in his work refers to the Chinese language as "Bijinche" (Beijingese). Another manuscript of the Tazkirah of Afaq Khoja speaks of Chin Shahar (China city) (LuA2, f. 36b). This reflects the geographical outlook of an oasis society, just as the name of the region, Altishahr, which means "six cities," does. ${ }^{7}$ As the name suggests, Altishahr was a collection of inhabited places in a matrix of insignificant space-more specifically, oases in the Taklamakan Desert. The name of any one of the "six" cities often denoted not just the city but the entire oasis in which the city was located. The region was usually described as a series of points on the landscape, rather than continuous space. Thus, it is not surprising that Altishahri authors would fail to distinguish between city and region, even in the case of the enormous Qing Empire. It is even possible that consumers of a text like the Tazkirah of Afaq Khoja actually imagined the khaqan of Chin to be the ruler of an oasis - a particularly distant oasis, with a particularly powerful army that allowed it to indirectly control other oases, such as the "six cities," but in the end an oasis just the same. Altishahris imagined China to be similar to their own indigenous oasis communities, applying their own geopolitical logic to their conceptualization of this other place called "China."

In sum, the indigenously authored texts of Altishahr depict China as a place and culture synonymous with its khan, and as a city. These characteristics are more or less particular to Altishahr, absent from the other networks of significance with which Altishahris engaged. By distinguishing these characteristics, I am suggesting that they are markers of a network of shared concepts that aligned roughly with the imagined boundaries of Altishahri identity. However, not all shared understandings employed in the Altishahri construction of China were limited to the region of Altishahr. It would be a mistake to associate those wider networks of meaning with Altishahr in particular, and it would be a mistake to let one kind of network-identity in the Barthian sense - dominate our explanation of Altishahr's China (Barth 1994). 


\section{Wider Networks of Meaning}

The word käfir (one who does not accept Islam) places our sample texts in a much wider network of meaning, embracing nearly all communities that valued the reading of the Quran, where the word appears frequently. ${ }^{8}$ The Altishahri application of the word käfir to the khaqan of Chin could have been understood almost anywhere in the Islamic world, regardless of local language differences. Rejection of Islam was the only descriptive characteristic given consistently to China across Altishahri authors. ${ }^{9}$ Usually unbelievers were called kāfir but they were occasionally described as idolaters (but parastlār). In addition to the passages already cited, kāfir appears frequently throughout both Mullā Bilāl's and Sayrāmī's histories, and less frequently in the Tazkirah of Afaq Khoja and Hājjī Ghulām's history.

The reputation of the Chinese as käfirs made them interchangeable with the Qalmaqs (Dzungar Mongols) to a great extent. For example, Sayrāmī described the scheme of an Altishahri leader who had captured a Qalmaq enemy of the Qing in language that emphasized the interchangeability of Khitay (China/Chinese/Manchus) and Qalmaq:

The arrival of Khitay soldiers in Ili became known. Taking counsel, he decided, "If I make a gift of this foul käfir [whom I have captured] to the unclean käfir who is coming, is there anything better than this?" and taking him, he set out. (Sayrāmī 1911, f. 23r)

Here the Qalmaq and the Khitay are described in almost identical language to highlight their interchangeability. A similar attitude appears in Sayrāmī's personal criticism of the feuding of Sufi leaders called "khojas," whose civil wars led to the domination of Altishahr, first by the Dzungars and then by the Qing. He wrote,

Giving themselves the names "White Mountain" and "Black Mountain," bringing misfortune and ruin upon themselves, and being disunited, [the khojas] gave over the homeland [yürt] and the people of the homeland to Qalmaqs and Khitays. (Sayrāmī 1911, f. 24v)

The interchangeability of kâfirs probably also facilitated some of the conceptual blurring between Chin and Machin and Khitay/Chin/Bijin. If the ancient enemy of Altishahri Muslims was not exactly identified with Qing overlords, it was equated with them morally. Both could be 
essentialized as the outrageous infidel other to the East. Indeed, in Mullā Bilāl's Holy War in China, which describes Muslim rebellions against infidel Qing rule, the Qing Empire is sometimes described as "Chin and Machin." Even though Bilāl's conflation is an outlier among a large body of texts that uphold the distinction, it suggests that connections between the two concepts were plausible. Such resonances brought the weight of the popular condemnation of "Chin and Machin," which the tazkirahs depict as an evil beyond the pale, to bear on the Qing Empire.

While kâfir was a word that could be understood throughout the Islamic world, it is important to understand its articulation with particularly Altishahri notions of Muslimness. The designation of China and the Qalmaqs as infidels seems at first to represent a hard and distinct line between Muslim and non-Muslim, with China firmly on the non-Muslim side. Indeed, these texts elsewhere make distinctions between a people called "Khitay," which includes Chinese and Manchu speakers, and the "Tungans," or Chinese-speaking Muslims. China's käfir identity is so strong that the people who are today called Muslim Chinese or Sino-Muslims are excluded from the Khitay category in Altishahri texts.

On closer inspection, however, it appears that there are degrees of Muslimness. The Tungans are represented as believers; one Tungan, for example, acts as deputy for the saint Muhammad Yūsuf in the Tazkirah of Afaq Khoja. And yet the Tungans do not share in the full Altishahri identity, which is defined by its Muslimness. Thus, when treating the interactions of the Tungans and the Altishahris, Mullā Bilāl refers to the language of the Altishahris as "Musulmanche" (Muslimese). And the Tungans are not the only believers to be excluded from the Muslim designation. In other Altishahri texts, Kirghiz believers are distinguished from "we Muslims" (Altishahris) (Kāshgharī c. 1770, f. 50a). The notion of "us" and "Muslim" bleed together so fully that, in order to be completely Muslim, one must be Altishahri. At the same time, Tungans and Kirghiz believers are never called käfir. This cautious use of käfir demonstrates some attention to the actual religious status (accepting or rejecting Islam) of those to whom it is applied, retaining its basic Quranic meaning in regard to Khitay. At the same time, the frequent use of terms of Muslimness to draw boundaries within the community of believers suggests that the use of kâfir as a label for China also functioned more generally as an Islamicized form of "othering." 
The Tazkirah of Áfāq Khvāja presents further gradations of belief in its many tales of conversions. Interestingly, conversion is something that happens to both Muslims and käfirs and always hinges on submission to a charismatic Sufi. Among käfirs, the Dalai Lama professes faith in Islam when Afaq Khoja wins a competition of miraculous powers. The nobles of Tibet then ask to profess the faith secretly (makhfi), so as not to upset their subjects. The khaqan of Chin himself converts when he is cured of a disease by ingesting the saliva of Afaq's father, known in the text as Mazār Pādishāhim. In the words of the text, "asking what Mazār Pādishāhim's secret was, he accepted the faith ['aqīda ikhlās qildilar]" (LuAK f. 15r). We are not told whether by doing so the khaqan has abandoned unbelief and shaken the description of käfir that characterized him in all earlier and later Altishahri treatments of China. When believers convert, they do so "to" Afaq or his father, Mazār Pādishāhim. For example, the text narrates that "all of the people in Sālā were Muslims. They converted [inābat qildilar] to Mazār Pādishāhim" (LuAK f. 16r). Even followers of Afaq are "converted anew" (yangībāshdin inābat qildilar) to Afaq when he conquers Kashgar (LuAK f. 57v).

These notions of faith reflect the workings of another network of significance, the strain of Central Asian Sufism marked by proselytization among rulers. The most famous group in this tradition is the Central Asian Naqshbandi order ${ }^{10}$ best represented in Western Turkestan by the political successes of Khoja Ahrar and in Altishahr by the competition between the White and Black Mountain khojas for influence with the khan of Yarkand. It was a network that included Western Turkestan, Altishahr, Gansu (Western China), and parts of the Tibetan Plateau. The notion of conversion promulgated in this network fit only imprecisely with the idea of $k \bar{a} f i r$ embedded in the network of Quranic readership, and the notion of Muslimness as it was used within the network of Altishahri identity maintenance. The intense competition for rulerdisciples turned personal loyalty to a particular Sufi leader into a prominent form of religious conversion.

The words "khan" and "khaqan" mark Altishahri participation in yet another network of meaning, one defined by political terminology that spanned the Inner Asian steppes, the settled regions of Central Asia, and, in the Qing era, China itself. The Qing emperor himself encouraged the use of the term "khan/khaqan," as part of a program of legitimacy that presented different faces to different subjects: the Son of Heaven to the Chinese, the Chakravartin king to the Tibetans, and the khan to the Manchus, Mongols, and Altishahris. The term "khan" was also 
used by Altishahr's neighbors to the West, the rulers of Khoqand, Bukhara, and Khiva, each of whom held the title. This was more than just a shared terminology. It brought with it particular understandings of relationships between ruler and subject, which affected the interactions of Altishahris and the Chinese state in ways that are explored further below.

In Hājj̄i Ghulām's text, a third network of significance is visible: the Persian literary tradition, which flourished not just in Persia but throughout Central Asia, parts of the Arab world, and parts of South Asia. Altishahris copied numerous Persian literary texts and, since the beginning of the eighteenth century, translated Persian texts into Turki. Just as importantly, professional storytellers mined these texts for tales that would entertain the audiences of public places such as the market, telling tales of Persian origin in the local Turki dialect. These were the “book reciters" of Abdu Vali Akhon's text quoted above.

The beginning of Hājjī Ghulām's history is strikingly similar to a common trope of Persian storytelling, shared also by the Arabic 1001 Nights, in which the story begins with a description of a powerful king who has no son. One such tale begins thus:

There was once, of old time, a king called Shehriman, who was lord of many troops and guards and officers and reigned over certain islands, known as the Khalidan Islands, on the borders of the land of the Persians; but he was grown old and decrepit, without having been blessed with a son, albeit he had four wives, daughters of kings, and threescore concubines, with each of whom he was wont to lie one night in turn. This preyed upon his mind and disquieted him, so that he complained thereof to one of his viziers, saying, "I fear lest my kingdom be lost, when I die, for that I have no son to take it after me."11

The similarities are unmistakable. The use of such an opening in a chronicle breaks with Altishahr's local historical tradition, and it is hard to imagine that Hājjī Ghulām was not strongly influenced by the Persian storytelling tradition. Hājjī Ghulām (or his sources) also had to do some bending of the facts to make it possible for his history to begin with such a tale. The Xuantong emperor ("Shentung," in Hājjī Ghulām's text) was five years old at the time of his deposition and could hardly have been concerned about sons. Some events described by Ghulām, especially the emperor's poisoning, seem to refer instead to the Guangxu emperor, who died three years before the beginning date of Ghulām's chronicle. The concern over the lack of a son better reflects the succession dispute that followed the Tongzhi emperor's reign (1856-1875), 
although Guangxu also died without a son. Melding these two or three emperors into a single individual allowed for a perfectly typical story opening, and therefore presumably made more sense to people who were steeped in the Persian storytelling tradition.

Finally, we see in Hājjī Ghulām's use of the word yamun his participation in a Chinese network of significance. This is obviously the Chinese 衙門 (yámén), the term for a local administrative compound. Here, Ghulām seems to understand the emperor's office through his local experience of Chinese rule. The emperor's court would not be called a yamen in Chinese, but by Ghulām's time, the yamen in Kashgar was an important node of China's colonial power in Altishahr, and the most easily accessible model of Chinese administration available to the author.

"China" was thus located at the intersection of religious status and identity through Altishahr's system of ethno-Islamic identity, while its emperor was bound up in the network of political relationships of the steppe through the use of the title "khan," its history was rendered by means of shared techniques of the Persian narrative tradition, and its power center was understood in terms of the local manifestations of the Qing Empire or Republic of China's bureaucratic power.

\section{Popular "Foreign" Texts on China}

Altishahris also consumed texts originally composed in other cultural contexts, without ever distinguishing such books as foreign. There were no clues in books like the Abu Muslim epic or the Alexander romance to reveal their foreign nature, and readers most likely considered them indigenous. Certainly such works were deemed just as authoritative as any locally authored text. $^{12}$

These books were not just read but also rewritten — by copyists. It seems that the effect of copying on copyists has not been discussed in scholarship on the world's various manuscript traditions. However, the copyists, who, in the Altishahri case, were often amateurs making copies for themselves, did not simply reproduce physical texts. They also formed the words and sentences of the texts over again in their thoughts, in their handwriting, and probably also with their lips, reinforcing the ideas embedded in the texts in a process quite different from that of 
reading. They not only consumed, but also recreated, the notions of China that appeared in popular "foreign" works.

Among the most notable of these books were Firdawsī's Shahnamah and the Alexander Romance, which again place the Altishahri "China" in a network of understandings shared by readers and writers of Persian literature. Here I will briefly treat the Shahnamah. ${ }^{13}$ The term "khan of Chin" also appears widely in the Shahnamah, but without the blending of person and place that is seen in works authored in Altishahr. "Chin" is commonly used alone to indicate a large geographical region and a kingdom. The Shahnamah sometimes calls China's ruler the "Faghfur of Chin," just as Sayrāmī’s history does (Firdawsī 1905, 262). ${ }^{14}$ The Shahnamah also associates Khotan with China through the phrase "Chin and Machin" (Firdawsī 1908, 46, 253, 265), while maintaining a distinction between the two, as has already been noted. In sum, the presence of the Shahnamah in the Altishahri literary and historical canons largely supports the notions of China already described, though without displaying the locally significant conflation of person and place.

\section{Practical Impact, Past and Present}

The shape of local imaginations of China had practical ramifications. For example, the khan-focused imagination of China influenced the way that the rebellions of 1864 unfolded. Altishahri witnesses understood the uprising as a rebellion against the khaqan of Chin as an individual, attributing the initial rebellion of the Sino-Muslims to outrage over a rumored letter from the khaqan himself, which supposedly ordered the massacre of the Sino-Muslims (Sayrām̄̄ 1911; Bilāl 1880). In the town of Kucha, where the revolt began, rebel crowds asked a former

beg to become their new khan. ${ }^{15}$ The former beg refused, out of personal loyalty to the khan, using language that reveals a commitment to Inner Asian steppe traditions, of which the khan of Chin was supposed to be a participant. Here is part of his speech to the crowd:

How can I wish to do ill [to the khan]? Although he is a käfir and without religion, for generations [my family] has eaten his salt and governed the country. Whatever the circumstances may be, I will not betray the lord who has given me salt. Maintaining the obligation of salt is obligatory [farz wäjib] for all people. (Sayrāmī 1911, 34a) 
Applying the "obligation of salt" to the Qing emperor marks the interaction of two networks of political discourse. The "obligation of salt" describes the moral duties of a vassal, especially to his khan, and is found throughout the Turkic world (Elçin 1966; Hamada 2001, 56). The concept is not, however, encountered in the political discourse of the Qing court or the Manchus in general. The Altishahri view of China-based rule as the rule of the khan activated the "obligation of salt" for the beg. It is hard to imagine that the "obligation of salt" would carry such weight if the Altishahris had viewed the Qing ruler through Chinese concepts such as huangdi (emperor) or "Son of Heaven."

The former beg's speech also highlights the contradictions inherent in the overlapping networks of meaning deployed to describe China. It demonstrates the beg's awareness that his decision was open to attack by opponents engaging the Quranic network of shared cultural meanings. Arguments based on the Quranic käfir were particularly dangerous, because the exploitation of the Quranic network could draw in actors apart from the Inner Asian and Turkic networks of political concepts. It held the potential to appeal to the Sino-Muslims (Tungans), who had begun the Kucha revolt and who had little awareness of the particular forms of loyalty due a "khaqan." While the notion of loyalty itself would hardly have been alien, an argument structured around the phrase "obligation of salt" was far less powerful for those outside the political discourse of Turkic Inner Asia. In the end, the crowd, which consisted of both SinoMuslims and Altishahris ("Tungans and Muslims"), was unconvinced, and the beg lost his life. Here it is important to see the use of käfir not as an Islamic influence, brought to Altishahr with Qarakhanid Islamicizing conquests of the eleventh century, but as an engagement with a network that still spanned geographies, states, languages, and identity groups, as did the obligation of salt.

The Altishahri conception of China as khan/khaqan also casts Qing attitudes toward its newest colony in a new light. The prevalence of the term "khan" meant that even before the Qing conquest, Altishahris shared a system of political legitimation with the Qing court, as the Manchus also conceived of their ruler as khan. Altishahr's own lineage of khans had been extinguished in the late seventeenth century. Thus, after the elimination of the Dzungars, the Qing had no competitors in Altishahr for the status of "khan," the highest political position in the Inner Asian and Central Asian worlds. Indeed, as Nathan Light has noted, Sayrāmī endeavored in his history (1911) to show that the Qing emperor was a legitimate successor to the Chinggisid khanship (Light 2012, 169).

Cross-Currents: East Asian History and Culture Review

E-Journal No. 12 (September 2014) • (http://cross-currents.berkeley.edu/e-journal/issue-12) 
It has been noted before that the Qing invested less in tailoring its politico-religious discourse to Altishahris than it did for other major conquered groups like the Tibetans and Mongols (Rawski 1998). This is less remarkable when we consider that the Altishahris and the Manchus were members of the same network of political significance. The Qing simply did not need to make a big investment in convincing Altishahris of its temporal legitimacy. However, this does not fully explain the lack of Qing ideological attention to Altishahr. The Mongols also shared a network of political legitimation with the Manchus, and the Qing worked hard to present the emperor as a patron of Mongol religion and politics. Perhaps the Mongols' military might earned this attention. However, even if the Altishahris were more distant and militarily weaker, the dangers of ideological disconnects were often demonstrated in open revolts. The Qing neglect of the Islamic network to which Altishahris also belonged frequently created crises of legitimacy, as rebels presented themselves as holy warriors fighting an infidel enemy. This does not, however, overshadow the fact that China was consistently imagined in Altishahr as the khan himself, without any dispute over the Chinese emperor's right to such a title. This consistent acceptance of the Qing ruler's temporal (but certainly not religious) legitimacy suggests that Qing ideological programs were more successful in Altishahr than previously thought, and therefore that the Qing court's limited efforts at legitimation were not necessarily as tepid as previously supposed.

Altishahri notions of China hold lessons for today's policy makers as well. As has been demonstrated, Altishahris' ideas of Islamic identity were shaped by their participation in multiple networks of significance. Conversion, Muslimness, and faith could therefore variously indicate allegiance to a charismatic Sufi preacher, membership in the Altishahri identity group, or acceptance of the Islam of the Quran. Today, Uyghurs often express anti-Chinese feelings in terms of belief or Muslimness. It is not rare to hear a Han Chinese person called a kaffir, and it is common to hear Uyghurs define themselves first and foremost as "Muslims." The latter term in particular should be seen as an ethnic term as much as a religious term. If policy makers can be made aware of the role of these terms in othering and identity maintenance and recognize that Uyghurs draw on multiple notions of belief and Muslimness, perhaps it would be possible to avoid distorting uses of the labels "fundamentalism" and "religious extremism." These last terms allow the Chinese government not only to ignore the very real grievances of ordinary Uyghurs 
but also to gain the complicity of other governments in the "strike hard" campaigns that define Beijing's approach to its colony in Xinjiang.

It is also important that all Altishahri mentions of China assume China to be an external, even distant, entity. Although Altishahr had been incorporated into the Qing Empire for 150 years by the time of Abdu Vali Akhon, that author still wrote about China, the "region of the khaqan," as a distant place that did not include Altishahr. According to Abdu Vali Akhon, vegetable seeds were brought from the region of the khaqan to Altishahr. This is not an exceptional text. No Altishahri text describes any part of Altishahr as a part of China in its own day. ${ }^{16}$ Although it was known that the Altishahri begs were vassals of the khaqan, their territory was not considered part of the "region of the khaqan." Despite the growing strength of the nation-state concept among Uyghurs over the last eighty years, the incorporation of Altishahr into the Chinese state still has not fully eliminated the Uyghur sense that China is a distant "other." Simply put, many Uyghurs do not consider themselves to be a part of China, and this understanding is not the product of a newly arrived nationalism. It is rooted in long-standing traditions shaped by the networks of meaning described above.

\section{What Does This Tell Us about the Notion of China?}

A deeper diachronic view of notions of China in Turkestan reveals a remarkable continuity. The phrase "khaqan of Chin" is at least as old as the Shahnamah (tenth century A.D.) and has served as an anchor for the alternate terms "Khitay" and "Șin.". 17 On the one hand, this view lends some credibility to the notion of China as a continuous entity. Surprisingly, it seems that Altishahr's inhabitants had a concept of China as one stable historical unit among many (to include, for example, Sukhur [Tibet] and Ferangi [Europe]), before Chinese authors ever elaborated such an idea. ${ }^{18}$ The Altishahri belief in "China" suggests that there is a Eurasian consensus on the existence of a durable cultural-political center of gravity by that name. At the same time, it is necessary to take seriously not only this Eurasian consensus but also Altishahr's particular construction of China. Doing so lends strength to a notion already common among non-Chinese scholars - the idea of "China proper"-for the Altishahri view did not consider Altishahr as a proper component of China, despite its incorporation into the Qing Empire.

The Altishahri case also reminds us of the cultural filters at work in our own concepts of China. The practical power of the word "khan" warns us of the ideological baggage that our own 
word "emperor" carries. It is hard to understand the "obligation of salt" when we are talking about an emperor, rather than a khan, and the sacrifice to heaven makes less sense for an emperor than for the Son of Heaven. This is, of course, nothing new, but it is interesting to see its effects from another cultural perspective. Our notion of China is also attached to our concepts of geography. The common emphasis on territory in defining China is encouraged not just by the current dominance of nationalist thought but also by the shared Chinese and Western emphasis on continuous, regular space, as opposed to the point- or place-based understanding that prevailed in Altishahr and expressed itself in the conception of China as a city.

\section{Conclusion}

The question "what is China?" lies at the center of any serious longue durée study of Chinese history, and the answers that scholars have offered have been vital to the destabilization of venerable myths and distortions. Not surprisingly, the thread that runs through all these answers is that "China" is a construction, a notion best expressed in Haun Saussy's description of China as an "artwork whose medium is history" (Saussy 1993, 151). Historians must admit, as they often do, that this work of art is the primary justification for considering either the various societies that have existed on the territory of what is now the People's Republic of China (PRC), or the various states that appear in the twenty-four standard histories to constitute a single, distinctive, and ontologically continuous entity. But whose artwork is this? The obvious (and paradoxical) answer is that it is China's artwork. However, Chinese historians have benefited from a growing number of collaborators in the last few centuries. Despite the ideological imperatives of PRC scholarship, Chinese history as produced over the last fifty years has been very much a product of a conversation among European, American, Japanese, and Chinese historians. In taking up, broadly, the dynastic narrative of the twenty-four histories of the imperial historiographical tradition, ${ }^{19}$ Western and Japanese historians have turned the local Chinese construction of China into a globally deployed paradigm. Even in studies that emphasize the constructedness of "China" or dispense with the dynastic model, the historical artwork of China defines the object of study. Indeed, the informed, even reluctant, acceptance of China as the object of study is the norm, present in everything from introductory works (e.g., Mitter 2008) to specialized monographs (e.g., Di Cosmo 2004). 
Tying the notion of "China" to particular cultures-Chinese, Japanese, European, American - undermines the presumed universal validity of the China concept, but it also requires us to ask the question: are there other such artworks called China? This article has pieced together one alternative construction of China from a society viewed as marginal by its Chinabased conquerors and colonizers: Altishahr in the nineteenth and twentieth centuries. If retrospective historical constructions are to define the Sinologist's object of study, then we should be familiar with the variety of such constructions that exist and have existed. Ironically, this may even lend plausibility to the notion of "China," by revealing a cross-cultural consensus on the existence of a cultural-political center of gravity on the eastern end of Asia. At the same time, it calls our own notion of China into question by making its cultural specificity obvious.

An examination of Altishahri notions of China is also useful for understanding the relationship between Islam and China. The Altishahri case shows that any examination of this relationship must engage multiple overlapping systems of meaning, not simply nation/civilization and religion. To emphasize the effect of a focus on overlapping networks of significance, I have (somewhat unnaturally) avoided tracing the origins of the various elements that together shaped the Altishahri "China." I have explored the grammar of these elements rather than their etymology, and mapped the geographic and cultural territory of their currency. The etymological approach is, of course, also an indispensible line of historical inquiry. It is worth knowing that the sonless king trope can be traced through Persia to India, and the term "khan" to the northeasternmost corner of the Inner Asian steppe over two millennia ago. Such knowledge alerts us to lost meanings and associated traditions that were present in the context of origin. It also allows us to tell the stories of how various networks of meaning grew and changed over time.

But etymological investigation, when overly emphasized, can distort our understanding of the past. It captures only a one-time, unidirectional influence, and it does so teleologically. It hides the continuing exchanges encouraged by shared ways of meaning. It masks the ability of a Persian merchant to understand an Altishahri history of China, of a Gansu Chinese Muslim to see belief as loyalty to Afaq Khoja (and to make a pilgrimage to his tomb in Altishahr), or of a Kazakh herder to share the Altishahri view of the Chinese emperor as khaqan. When such interactions do appear in the etymological approach, they are seen as cross-cultural, rather than intra-network, exchanges. Attention to the grammar of wider networks of significance captures 
these continuing interactions and accounts better for the intense sharing of cultural material that has characterized Eurasia for two millennia. It also allows us to see culture as a vast series of overlapping networks of shared meanings that defy boundary drawing, rather than bounded, essentialized puzzle pieces. We can then leave it to the individual participants in these networks to draw the conceptual boundaries that create identity groups, without letting those boundaries blind us to exchanges that continue across imagined borders.

The etymological approach also lends itself to the continued positing of idealized, pure, cultural units. For periods after the Tang dynasty, the pure, Islam-free China and the pure, Chinafree Islam can be sustained as relevant ideas only if we continually look back to that very brief period between the time of the Prophet Muhammad and the arrival of the first Muslims in China. Etymological studies do just that, maintaining the fiction of pure, mutually exclusive China and Islam by tracing connections to a time when such pure units are supposed to have existed. As such, etymology is the engine of the syncretism model that is so prominent in the study of Islam and China. No matter how absurd it may be to conceive of China as essentially non-Islamic after thirteen hundred years of Muslim presence in China, one can always recuperate the notion of a pure, Islam-free China by tracing Islam back in time to its non-Chinese origins, and China back to its pre-Islamic existence.

The importance of so many overlapping networks of meaning to Altishahri understandings of Islam and China also invites us to examine closely the phrase "Islam in China." This phrase has come to define a small academic field, and yet we have scarcely considered its implications or how it shapes our inquiries. "Islam in China" confronts us with the odd juxtaposition of a global complex of religious traditions and a nation, subsuming the former under the latter. It elevates these two categories of analysis above others, such as class, scholarly networks, literary traditions, foodways, and genealogies, and it leads scholars to imagine the development of Islamic traditions in terms of unidirectional "influences" and "syncretism" rather than overlapping networks of meaning and exchange. Ironically, it also imposes a mental segregation of China and Islam. It leaves room for exotic Muslim minorities in China, and also Chinese Muslims, but the "real" China is assumed to remain largely untainted by Islam, and the "real" (nonsyncretic) Islam untainted by Chinese cultures. Muslims in China are treated as though they had compromised their claims to full participation in either of these larger identities. We have circumscribed them to keep Islam and China distinct. We can see the effectiveness of 
this segregation by observing how strange it seems to speak of "China's Islamicness" or "Islam's Chineseness." There are Muslims in China, but somehow China escapes being Islamic. Apart from studies of "syncretic" or "mixed" forms, no one has yet asked how Islam, as a global phenomenon, has been Chinese. In such an environment, even an inversion of the common phrase "Islam in China" is uncomfortable.

Rian Thum is assistant professor of history and Loyola University New Orleans. The author would like to thank the organizers, participants, and sponsors of the conference for which this paper was originally written: "Forms of Exchange: China and the Muslim World," sponsored jointly by UC Berkeley's Institute of East Asian Studies, Center for Middle Eastern Studies, and Institute of Slavic, East European, and Eurasian Studies.

\section{Notes}

1 This is an assumption shared with lay English usage of the word "China," but one that, as the New Qing Historians have demonstrated, does not withstand close scrutiny. The work of Rawski (1998), Elliott (2001), Crossley (2002), and many others has shown that China was treated by its Qing rulers as one among several components of the Manchu-ruled Qing Empire.

2 "The region [kishwar] of Chin" (LuMK, f. 26b) and "Chin city" (Hajji c. 1700-1849, f. 86a).

3 Inscription from the interior of the tomb of Muhammad Sharif in Yarkand. The translation comes from Brophy and Thum (forthcoming).

4 This list is not exhaustive. In particular, I have not been able to consult several unique manuscripts treating the history of the 1864 rebellions.

5 Elsewhere, Mullā Bilāl also calls him "shah of Chin and Machin."

6 Such distinctions never appear in any Altishahri texts.

7 The number was conventional. There were more than six cities, and there was no agreement on which of them were the six referred to by the word Altishahr.

8 It appears twenty-six times as a simple noun with the meaning of "infidel" and many more times in verbal and other forms.

9 Tyranny (zulm) is also mentioned in several works, but it is often applied to specific periods or situations and is not applied with the universality of unbelief.

10 For a non-Naqshbandi representative of this tradition, see Muhammad Sharif, a saint whose status has been the subject of much study (Baldick 1993; DeWeese 1996; DeWeese 2011).

11 Payne's 1901 translation of the tale of "Kemerezzeman and Budour" (100). The trope also appears in the story of "Ma'ruf the Treasure Seeker." For another example, see the Sindibādnäma. W. A Clouston calls this trope the "regulation' opening of by far the greater number of Asiatic stories" and considers it a sign of Indian origins (Clouston 1887, 576). 
12 For a colorful demonstration of the Alexander Romance's perceived veracity, see the marginal note in Iskandarnämah (Manuscript \# Prov 324, Jarring Collection), which says, "This is the Iskandarnamah, whoever should say it is a lie, his mouth shall be filled with sheep droppings" (f. 46a). More pertinently, the few Altishahri texts that record textual sources make no distinction between local and foreign works.

13 The Shahnamah is particularly useful because it combined relatively wide circulation with extensive treatment of China.

14 On the connections of this title to the Parthian Pahlavi baghpuhr (son of God) and the Sogdian baghpür, see Bearman et al. (2014). For the title on a Kushan inscription, see Maricq (1958).

15 This is a sign of how successfully the begs maintained their own legitimacy as Islamic rulers, even while serving an infidel khan.

16 In certain cases of conflation of "Chin and Machin" with Qing China, Khotan might be seen as a former part of China.

17 Cina, as is well known, is much older, perhaps traceable to the Qin dynasty.

18 Ironically, after such an idea was articulated within China in the late eighteenth and early nineteenth centuries, the continuity of an essential China became a tool of the People's Republic of China for the domination of the Uyghurs, whose land is now considered "an inseparable part of our great motherland" (Dong and Jiang 1991, 13).

19 In the sense that anything treated as "us" in the twenty-four histories is considered to be China.

\section{References}

Abdul Vali Akhund. c. 1905-1910a. Changchile Bayani. Manuscript \# Prov 207, AV 28, Jarring Collection, Lund University Library.

. c. 1905-1910b. Otyash Bayani. Manuscript \# Prov 207, AV 3, Jarring Collection, Lund University Library.

Baldick, Julian. 1993. Imaginary Muslims: The Uwaysi Mystics of Central Asia. New York: New York University Press.

Barth, Fredrik. 1994. "Enduring and Emerging Issues in the Analysis of Ethnicity." In The Anthropology of Ethnicity: Beyond "Ethnic Groups and Boundaries," edited by Hans Vermeulen and Cora Govers, 11-32. Amsterdam: Het Spinhuis.

Bearman, P., Th. Bianquis, C. E. Bosworth, E. van Donzel, and W. P. Heinrichs. 2014. "Faghfür." In Encyclopaedia of Islam, 2nd ed. BrillOnline.

Bilāl, Nazym. 1880. Kitāb-i Ghazāt Dar Mulk-i Chīn. Published as Voina Musul'Man Protiv Kitaitsev: Tekst Nariechiia Taranchi, edited by Nikolai Pantusov. Kazan: V Univ. tip. Brophy, David, and Rian Thum. Forthcoming. "The Shrine of Muhammad Sharīf and its QingEra Patrons." In The Biography of Muhammad Sharif, edited and translated by Jeff Eden. Vienna: Austrian Academy of Sciences Press.

Clouston, W. A. 1887. "Variants and Analogues of the Tales in the Supplemental Nights, vol. III" In Supplemental Nights to the Book of the Thousand Nights and a Night, by Sir Richard Francis Burton, 3:554-652. London: The Burton Club. 
Crossley, Pamela Kyle. 2002. A Translucent Mirror: History and Identity in Qing Imperial Ideology. Berkeley: University of California Press.

DeWeese, Devin. 1996. "The Tadhkira-i Bughrā-Khān and the 'Uvaysī' Sufis of Central Asia: Notes in Review of Imaginary Muslims." Central Asiatic Journal 40 (1): 87-127. . 2011. "The 'Competitors' of Ishạa Khwāja in Eastern Turkestan: Hagiographies, Shrines, and Sufi Affiliations in the Late Sixteenth Century." In Horizons of the World: Festschrift for İsenbike Togan, edited by İlker Evrim Binbaş and Nurten Kılıç-Schubel, 133-215. Istanbul: İthaki.

Di Cosmo, Nicola. 2004. Ancient China and Its Enemies: The Rise of Nomadic Power in East Asian History. Cambridge, UK: Cambridge University Press.

Dong Qingxuan, and Jiang Qixiang. 1991. Xinjiang Qianbi. Ürümchi: Xinjiang meishu sheying chubanshe.

Elçin, Şükrü. 1966. “Tuz-Ekmek Hakkı Deyimi Üzerine.” In Reşid Rahmeti Arat Için, 164-171.

Elliott, Mark C. 2001. The Manchu Way: The Eight Banners and Ethnic Identity in Late Imperial China. Stanford, CA: Stanford University Press.

Firdawsī, Abu'l-Qāsim. 1905. The Sháhnáma of Firdausí. Translated by A. G. Warner and E. Warner. Vol. 1. London: Kegan Paul, Trench, Trübner, and Co. . 1906. The Sháhnáma of Firdausí. Translated by A. G. Warner and E. Warner. Vol. 2. London: Kegan Paul, Trench, Trübner, and Co.

—. 1908. The Sháhnáma of Firdausí. Translated by A. G. Warner and E. Warner. Vol. 3. London: Kegan Paul, Trench, Trübner, and Co.

Frankel, James D. 2011. Rectifying God's Name: Liu Zhi's Confucian Translation of Monotheism and Islamic Law. Honolulu: University of Hawai'i Press.

Ghulām, Hājjī Muḥammad Khān Khwājam. 1927. Kāshghar Mā Tìtaynīng Vāqi 'asi. Manuscript \# Prov 163, Jarring Collection, Lund University Library.

Gladney, Dru C. 1987. "Muslim Tombs and Ethnic Folklore: Charters for Hui Identity." The Journal of Asian Studies 46 (3): 495-532.

Hai Xiaohong. 2013. "Jicheng Yu Tiaoshi: Ru, Yi Wenhua Jiaorong Zhong de Huizu Yueliang Meixue." Minzu wenxue yanjiu 6:51-57.

Hajji, Mullā. c. 1700-1849. Tazkirat al-Bughrā-khān, in an untitled compilation of tazkirahs. Manuscript \# Prov 73, Jarring Collection, Lund University Library.

Hamada Masami. 2001. "Jihäd, Hijra et «devoir du sel» dans l'histoire du Turkestan Oriental." Turcica 33:35-61.

Iskandarnāmah. Manuscript \# Prov 324, Jarring Collection, Lund University Library.

Israeli, Raphael. 2002. Islam in China: Religion, Ethnicity, Culture, and Politics. New York: Lexington Books.

Kāshgharī, Muhammad Șādiq. c. 1770. Tažkirah- $i$ 'Azīzān. Bodleian Library, Manuscript \# Ms. Ind. Inst. Turk 3.

Light, Nathan. 2012. "Muslim Histories of China: Historiography across Boundaries in Central Eurasia." In Muslim Histories of China: Historiography across Boundaries in Central Eurasia, edited by Zsombor Rajkai and Ildikó Bellér-Hann, 151-176. Wiesbaden: Harrassowitz Verlag.

Lipman, Jonathan N. 1998. Familiar Strangers: A History of Muslims in Northwest China. Seattle: University of Washington Press.

Maricq, André. 1958. "La grande inscription de Kanișka et l'étéo-Tokharien, l'ancienne langue de la Bactriane." Journal Asiatique 246 (4): 345-440. 
Martin, Luther H. 1996. "Syncretism, Historicism, and Cognition: A Response to Michael Pye." Method and Theory in the Study of Religion 8 (2): 215-224.

Mitter, Rana. 2008. Modern China: A Very Short Introduction. Oxford, UK: Oxford University Press.

Payne, John, trans. 1901. The Book of the Thousand Nights and One Night: Now First Completely Done into English Prose and Verse, from the Original Arabic. Vol. 3. London: [no publisher named, "printed for subscribers only"].

Rawski, Evelyn. 1998. The Last Emperors: A Social History of Qing Imperial Institutions. Berkeley: University of California Press.

Saussy, Haun. 1993. The Problem of a Chinese Aesthetic. Stanford, CA: Stanford University Press.

Sayrāmī, Mullā Mūsá. 1911. Tārikh-i Hamīd̄̄. Manuscript \# Prov 163, Jarring Collection, Lund University Library.

Tazkkirah-i Āfāq Khvājah (LuAK), in an untitled compilation of tazkirahs. Manuscript \# Prov 369, Jarring Collection, Lund University Library.

Tazkirah-i Áfāq Khvājah (LuA2), in an untitled compilation of tazkirahs. Manuscript \# Prov 22, Jarring Collection, Lund University Library.

Tazkirah-i Imām Ja far Tayarān (BaJT), in an untitled compilation of tazkirahs. Call number 4MS BP193.16.A3 1800z, Bancroft Library, University of California, Berkeley.

Tazkīrah-i Imām Mūsá Kāzìm (SpMK), in an untitled compilation of tazkirahs. Manuscript \# C551, St. Petersburg Institute of Oriental Manuscripts.

Tazkkirah-i Imām Mūsá Kāżim (LuMK), in an untitled compilation of tazkirahs. Manuscript \# Prov 102, Jarring Collection, Lund University Library.

Tazkirah-i Türt Imām Zabihlar (LuTI), in an untitled compilation of tazkirahs. Manuscript \# Prov 73, Jarring Collection, Lund University Library.

Tazkirah-i Türt Imām Zabiḥlar (LuT2), in an untitled compilation of tazkirahs. Manuscript \# Prov 349, Jarring Collection, Lund University Library.

Thum, Rian. 2012. "Modular History: Identity Maintenance before Uyghur Nationalism." The Journal of Asian Studies 71 (3): 627-653.

- 2014. The Sacred Routes of Uyghur History. Cambridge, MA: Harvard University Press. 